\title{
SIRAH DALAM MENEGAK PERUBAHAN SOSIAL MENGIKUT PANDANGAN SYEIKH SAID RAMADAN AL-BUTI
}

\author{
Nurul Salsabila Abu Bakar dan Mohd Nazri Ahmad \\ Fakulti Pengajian Islam Universiti Kebangsaan Malaysia \\ salsabilagpc@gmail.com
}

Diterima 25 Maret 2018| Direview 01 September 2018 |Diterbitkan 31 Desember 2018

Abstract:

The life of Prophet Muhammad/ Sirah Rasullullah, SAW, (peace and blessings of Allah be upon him) is one of the written works of scholars to be featured as having played a major role in developing da'wah and Islamic Shari'ahs around the world from the past. The bond between Moslems and the prophet is strong so the Moslems can use sirah as a reference to strengthen faith, morals, foster the struggle of Islam and encourage the Muslim to hold on to the truth. This study will highlight the role of the sirah in strengthening the social aspect of society and this will be seen based on the views of Sheikh Ramadan al-Buti. Content analysis is used to analyze Figh as-Sirah an-Nabawiyyah. The data was analysed descriptively and explanatory. The findings show that the need for a sirah approach in the social aspect is high for the good of social aspect itself. However, Syeikh Ramadan al-Buti has opened the opportunity so that the aspects of the sirah is applied to the social change of the Islamic society from time to time. The implications of the study show that the Prophet's sirah/life has succeeded in forming a good Islamic Government over the history of Western civilization.

Keywords: Sirah, social aspect, Syeikh Ramadan al-Buti

\begin{abstract}
Abstrak:
Sirah Rasulullab SAW merupakan salah satu karya penulisan ulama perlu diketengahkan kerana telab memainkan peranan yang besar dalam mengembangkan dakwah dan syariat Islam diselurub dunia sejak dabulu lagi. Mempelajari sirah Nabi ini bukanlah semata-mata untuk mengetabui peristiwa menarik dan aneh yang berlaku di zaman Nabi SAW. Pengkajian sirah ini juga bukan sekadar ingin mengetahui peristiwa-peristiwa yang telah melakar sejarah sebagaimana kajian-kajian sejarah yang lain sebagai contoh sejarah hidup seorang khalifah atau sejarah tamadun yang silam. Sirah juga bukanlah sekadar satu kisah yang dibaca pada hari keputeraan baginda $S A W$ sahaja. Apa yang lebih besar sebenarnya adalab ikatan seseorang Muslim dengan Rasulnya sehinggakan pada akhirnya Muslim itu berjaya menjadikan sirah sebagai sesuatu yang dapat menambabkan iman, memperelok akblak,
\end{abstract}


menyemarakekan perjuangan Islam serta dapat mendorong Muslim itu untuk terus berpegang dengan kebenaran dan seterusnya istiqamah kepadanya. Kajian ini akan mengetengabkan peranan sirah dalam mengukubkan aspek sosial masyarakat dan perkara ini akan dilihat berdasarkan kepada pandangan Syeikh Ramadan al-Buti. Kaedah analisis kandungan akan digunakan dalam mengkaji kitab Fiqh as-Sirah an-Nabawiyyah bagi mendapatkan data. Data tersebut akan dianalisis secara deskriptif dan eksplanatori. Dapatan kajian menunjukean bahawa keperluan pendekatan sirah dalam aspek sosial adalah tinggi bagi membentuk aspek sosial yang baik itu sendiri. Walau bagaimanapun, Syeikh Ramadan al-Buti telah membuka ruang sepenubnya supaya aspek sirah diaplikasikan kedalam perubahan sosial masyarakat islam dari masa ke semasa. Implikasi kajian menunjukkan bahawa sirah Rasulullah telah berjaya membentuk satu Kerajaan Islam yang baik berbanding sejarah tamadun Barat yang musnah ekoran tiada sisa-sisa kemanusiaan yang dibidupkan.

Kata kunci: Sirah, aspek sosial, Syeikh Ramadan al-Buti

\section{Pendahuluan}

Para ulama sememangnya telah memainkan peranan penting dalam perkembangan dan penyebaran Islam. Kehebatan seseorang ulama dibuktikan dengan disiplin dan keprihatinan mereka yang tinggi terhadap ilmu pengetahuan. Syeikh Ramadan al-Buti merupakan seorang penulis yang telah menghasilkan puluhan karya dalam pelbagai bidang keilmuan Islam terutama dalam bidang syariah, akidah, tasawuf, sosial dan dakwah. Penulisan beliau sangat bermanfaat sehinggakan sebahagian besar karya tersebut dijadikan teks dalam kurikulum pendidikan untuk dipelajari oleh generasi pada masa kini sama ada secara formal atau tidak formal.

Pelbagai kajian telah dilakukan untuk menonjolkan kehebatan Syeikh Ramadan al-Buti. Rumaizudin Ghazali ${ }^{1}$ mengkaji pandangan akidah Syeikh Ramadan al-Buti melalui buku Kubra al-Yaqiniyyat al-Kawniyyat. ${ }^{2}$ Rashidi \& Hadzrullathfi mengkaji tentang kerangka asas pemikiran akidah Syeikh Ramadan al-Buti sebagai seorang tokoh ulama kontemporari. ${ }^{3}$ Andreas Christman mengkaji tentang ketokohan dan kepakaran Syeikh al-Buti sebagai

\footnotetext{
1 Mohd Rumaizuddin Ghazali, Pandangan Akidab Mubammad Sa'id Ramadhan Al-Buti Dalam Buku Kubra Al-Yaqiniyyat Al-Kawniyyat, 2011.

${ }^{2}$ Muhammad Said Ramadan al-Buti, Hadha Waladi. Damsyik: Dar Al-Fiker.

${ }^{3}$ Muhammad Rashidi Wahab \& Syed Hadzrullathfi Syed Omar, Kerangka Asas Pemikiran Tokoh Ulama Akidah Kontemporari: Muhammad Sa’id Ramadhan Al-Buti (Bangi: UKM, 2011).
} 
seorang ulama yang disegani. ${ }^{4}$ Zulkifli al-Bakri pula mengkaji tentang kehebatan dan sumbangan dakwah Syeikh al-Buti sepanjang berguru dengan beliau. ${ }^{5}$ Rumaizudin Ghazali mengkaji ketokohan Syeikh al-Buti dalam bidang akidah dan ketamadunan. ${ }^{6}$

Manakala dalam "The Royal Islamic Strategic Studies Centre" mengkaji tentang kehebatan Syeikh al-Buti yang tersenarai dalam 500 Muslim yang banyak sumbangannya. ${ }^{7}$ Thomas Pierret mengkaji tentang keintelektualan dan ideologi Syeikh Ramadan al-Buti. Ebehard Troeger (2010) menumpukan berkenaan dengan kritikal analisis Syeikh Ramadan al-Buti berdasarkan kehidupan Rasulullah SAW. Sirah sangat berperanan dalam membentuk masyarakat yang berakhlak dan mengamalkan islam dalam kehidupan seharian. Kita juga dapat melihat pengaplikasian sirah dalam masyarakat telah diamalkan sepenuhnya atau belum.

\section{Metode}

objektif artikel ini ialah untuk mengetengahkan peranan sirah dalam mengukuhkan aspek sosial masyarakat berdasarkan kepada pandangan Syeikh Ramadan al-Buti dan menganalisis pandangan beliau melalui kitab Fiqh Sirah. Kaedah analisis kandungan akan digunakan dalam mengkaji kitab Fiqh Sirah bagi mendapatkan data. Data tersebut akan dianalisis secara deskriptif, kemudian akan di eksplanatorikn secara bertema. Tema yang ditetapkan adalah pembinaan akidah, kebudayaan, sistem kemasyarakatan dan ekonomi Islam.

\section{Latar Belakang Ringkas Syeikh Ramadan al-Buti}

Syeikh Ramadan al-Buti telah dilahirkan pada tahun 1929 di sebuah perkampungan kecil di Turki yang bernama Jilka. Mendapat gelaran al-Buti kerana nisbah kepada tempat kelahirannya yang terletak di Kepulauan Butan atau Kepulauan Ibnu Umar di timur laut Syiria. Nama sebenar beliau ialah Muhammad Sa'id bin Ramadan bin Umar bin Murad. ${ }^{8}$ Menurut Syeikh Ramadan al-Buti, bapanya yang lebih masyhur dengan nama Mulla Ramadan

\footnotetext{
${ }^{4}$ Andreas Christmann, Islamic Scholar and Religious Leader: A Portrait of Shaykh Mubammad Sa'id Ramadhan Al-Buti (London: I.B. Tauris, 1998).

${ }^{5}$ Zulkifli al-Bakri, Syarah Al-Hikam. Jil.1 (Negeri Sembilan: Jabatan Mufti, 2006).

${ }^{6}$ Mohd Rumaizuddin Ghazali, Pandangan Akidah Mubammad Sa'id Ramadhan Al-Buti Dalam Buku Kubra Al-Yaqiniyyat Al-Kawniyyat.

7 The Royal Islamic Strategic Studies Centre, The 500 Most Influential Muslims In The World 2010 (Urdun: al-Mamlukak al-Urduniyyah al-Hashimiyyah, 2010).

${ }^{8}$ Muhammad Said Ramadan al-Buti, Hadha Waladi. Damsyik: Dar Al-Fiker.
} 
merupakan seorang ulama Kurdi yang lahir pada tahun $1888 .{ }^{9}$ Bapanya belajar di beberapa buah sekolah dan berguru dengan dengan guru-guru secara talaqqi. Syeikh Mulla berguru dengan ulama-ulama yang hebat seperti Syeikh Muhammad Said Sayyid, Syeikh Muhammad al-Fanzaki dan Mulla Abdul Salam. ${ }^{10}$ Tidak disangkal lagi bahawa kehebatan Syeikh Ramadan al-Buti juga dpengaruhi oleh latar belakang ayahnya sendiri iaitu Syeikh Mulla.

Pendidikan Syeikh Ramadan al-Buti bermula seawal usia enam tahun dengan mula mempelajari dan menghafal al-Quran daripada seorang guru wanita. Syeikh Ramadan al-Buti berjaya menghabiskan bacaan al-Quran dalam masa enam bulan. Setelah itu, Syeikh Ramadan al-Buti dihantar ke sekolah rendah di Zaqaq al-Qarmani berdekatan Suq Sarujah (pasar Sarujah). Di sekolah inilah Syeikh Ramadan al-Buti mempelajari agama Islam, bahasa Arab, matematik dan pelajaran yang lain. ${ }^{11}$

Dalam masa yang sama, bapanya selaku guru utama kepada Syeikh Ramadan al-Buti telah mengajarnya dengan pelbagai ilmu khususnya ilmu kegamaan iaitu ilmu akidah islam dan ilmu sirah Rasulullah SAW. Selain menghafal karya ulama silam 'Ukud al-Jaman' karya Imam al-Suyuti, Syeikh alButi turut mempelajari ilmu balaghah, mantik,syair dan fikah. Walau bagaimanapun, pembelajaran yang diberikan bapanya tidak berhenti dengan aspek keilmuan semata, namun turut dididik dengan aspek kerohanian dan akhlak. $^{12}$

Pada tahun 1953M, Syeikh Ramadan al-Buti menamatkan pengajian menengahnya di Maahad at-Taujih al-Islami di Damsyik. Pada tahun 1955 beliau telah berjaya memperolehi ijazah Syahadah 'Alamiyah. Tahun berikutnya pula, beliau memasuki Fakulti Bahasa Arab juga di Universiti al-Azhar dan telah memperolehi Diploma pendidikan pada akhir tahun yang sama. Seterusnya, Syeikh Ramadan al-Buti dihantar oleh pihak universiti untuk meneruskan lagi pengajian di Fakulti Syariah Islamiyyah di Universiti al-Azhar untuk mendapatkan ijazah ph.D dalam bidang Usul Syariah Islamiyah dan berjaya memperolehinya pada tahun $1965 .{ }^{13}$

Syeikh Ramadan al-Buti merupakan seorang penulis yang sangat profilik. Permulaan penulisannya bermula sejak di peringkat sekolah menengah

\footnotetext{
${ }^{9}$ Ibid.

${ }^{10}$ Ibid.

${ }^{11}$ Ibid.

12 Ibid.

${ }^{13} \mathrm{Ibid}$
} 
lagi dengan menghantar sebuah artikel di Majalah al-Tamadun al-Islami yang berjudul Amam al-Mar'ah (Di Hadapan Wanita). Penerbitan artikel ini merupakan satu titik perangsang dan kegembiraan kepada dirinya. Rentetan dari penerbitan artikel itu, semasa di Kaherah Syeikh al-Buti mula menulis kisah seorang tokoh sasterawan yang dikenali sebagai Kurdi Mamu Zain. ${ }^{14}$

Dalam pada itu, buku-buku yang ditulis oleh beliau sangat diminati oleh umat Islam seluruh dunia terutama buku Fiqh as-Sirah an-Nabawiyyah. ${ }^{15}$ Bahkan buku tersebut telah diulang cetak berpuluh-puluh kali dan diterjemahkan ke dalam pelbagai bahasa. Buku-buku penulisannya inilah yang dapat menjelaskan pemikiran dan sumbangannya kepada dunia ilmu dan medan dakwah. ${ }^{16}$

Buku fiqh al-Sirah merupakan tulisan Syeikh Ramadan al-Buti pada tahun 1999. Kitab fiqh sirah merupakan kitab yang mengkaji tentang Sirah Nabi Muhammad SAW. Kitab ini juga pernah dijadikan sebagai sumber pengajaran kepada mahasiswa tahun pertama Fakulti Syariah Universiti Damsyik. ${ }^{17}$

Jika ditelusuri, sungguh besar sumbangan Syeikh Ramadan al-Buti dalam aspek sirah terutama pada bahagian penulisan. Hal ini kerana, penulisan sirah oleh Syeikh al-Buti ini mempunyai kelebihan dan keunikan yang tersendiri. Buku Fiqh as-Sirah an-Nabawiyyah ini memaparkan kajian sirah Rasulullah SAW yang mengikuti garis-garis sirah Nabi bahkan disertakan pula dengan peristiwa-peristiwa sejarah disuatu bahagian yang berasingan. ${ }^{18}$

Oleh itu, setelah diteliti sumbangannya yang menyerlah dalam mengangkat martabat sirah Rasulullah SAW, ternyata Syeikh Ramadan al-Buti meletakkan tujuan yang besar dalam kajian riwayat hidup Rasulullah SAW ini. Bagi beliau penulisan ini bukanlah semata-mata kajian untuk melihat kejadian dan episod bersejarah atau cerita indah, namun kajian sirah yang dimaksudkan ialah supaya setiap dari Muslim dapat memahami, menganggap dan menggambarkan bahawa zahir dan batin Islam semuanya telah teradun lengkap di dalam kehidupadan diri Rasulullah SAW itu sendiri. ${ }^{19}$

\footnotetext{
${ }^{14}$ Damronih, Pengenalan: Pengantin Syurga (Jakarta Timur: Dar al-Fikr, 2009).

${ }^{15}$ Muhammad Said Ramadan al-Buti, Hadha Waladi. Damsyik: Dar Al-Fikr.

16 Mohd Rumaizuddin Ghazali, Pandangan Akidah Mubammad Sa'id Ramadhan Al-Buti Dalam Buku Kubra Al-Yaqiniyyat Al-Kawniyyat.

${ }^{17}$ Mohd Darus Sanawi \& Mohd Yusuf Haji Ismail, Terj. Fiqh as-Sirah (Selangor: Dewan Pustaka Fajar, 2008).

${ }^{18}$ Muhammad Said Ramadan al-Buti, Hadha Waladi. Damsyik: Dar Al-Fikr.

${ }^{19}$ Muhammad Said Ramadan al-Buti.
} 


\section{Berbagai Peranan Sirah dalam Aspek Sosial}

1. Usaha Membina Akidah

Manusia sebelum kedatangan Islam berada dalam keadaan yang rosak, berpecah belah dan meletakkan perbezaan kemuliaan darjat sesama manusia. Rahgib Sirjani dalam kitabnya Madza Qaddamal Muslimuna lil Alam Ishamaatu al-Muslimin fi al-Hdharah al-Insaniyah menyenaraikan lima peradaban yang sedang porak peranda dengan penyimpangan nilai-nilai kemanusiaan dan akhlak sebelum mendapat cahaya Islam. ${ }^{20}$ Dalam kitab Fiqh Sirah, Syeikh Ramadan al-Buti mengulas secara ringkas berkenaan dengan lima peradaban tersebut iaitu kerajaan Greek, India, Parsi dan Romawi serta Semenanjung Arab yang menjadi arena perpecahan agama dan falsafah yang berbagai corak. ${ }^{21}$

Menurut Raghib Sirjani, Parsi merupakan sebuah kerajaan yang membangun dengan cemerlang pada pertengahan kurun ketiga sebelum Masihi. Bidang politik, kenegaraan dan peperangan mereka begitu teguh dan berkuasa. ${ }^{22}$ Walau bagaimanapun, al-Buti mengatakan ketika Yazdajrid II menaiki tampuk pemerintahan, akidah pembesar dan pemerintah Parsi keseluruhannya menganut agama Majusi (Zuraidisy) ${ }^{23}$ yang mana ajaran ini menurut Abu Hasan an-Nadawi, ia tidak mengikat penganutnya dengan sebarang perkara hukum, perdagangan, politik dan kemasyarakatan. ${ }^{24}$ Mereka bebas melakukan apa sahaja yang dapat memenuhi kepuasan jiwa dan kehendak mereka

Menurut Arthur Cristensen, Sejarah menunjukkan Yazdajrid II yang menjadi pemerintah pada pertengahan abad kelima Masihi telah berkahwin dengan anak perempuannya sendiri dan kemudian telah membunuhnya. Pada abad keenam, Bahram Jubain ketika itu berkuasa telah berkahwin dengan adik beradiknya sendiri. Bagi mereka, perkahwinan yang tanpa ada pengecualian batas keluarga bukanlah sesuatu yang dianggap tidak baik malah ianya dianggap sebagai perbuatan baik sebagai jalan mendekatkan diri kepada Allah.

\footnotetext{
${ }^{20}$ Rahgib as-Sirjani, Sumbangan Peradaban Islam pada Dunia (Jakarta: Pustaka al-Kautsar, 2006).

${ }^{21}$ Muhammad Said Ramadan al-Buti, Hadha Waladi. Damsyik: Dar Al-Fikr.

${ }^{22}$ Rahgib as-Sirjani, Sumbangan Peradaban Islam pada Dunia.

${ }^{23}$ Muhammad Said Ramadan al-Buti, Hadha Waladi. Damsyik: Dar Al-Fikr.

${ }^{24}$ Abu al-Hasan an-Nadawi, Madza Khasira Al-Alam Bi Inhithath Al-Muslimin (Kairo: Maktabah as-Sunnah, 1990).
} 
al-Imam al-Shahrastani dalam kitabnya yang bertajuk al-Milal wa alNihal menyebut, terdapat antara ajaran Mazdak yang menyebut bahawa kebebasan menggunakan harta benda menjadikan kaum wanita sebagai hak milik bersama yang mana ia tidak ubah seperti air, api dan rumput di mana semua manusia boleh berkongsi tampa sekatan. Hawa nafsu telah tersebar dan bermaharajalela dalam kalangan para pemuda, orang-orang kaya serta orang yang lapang kerana hidup semata-mata untuk bersuka ria.

Bangsa Parsi akhirnya tenggelam dalam pengaruh hawa nafsu dan ketandusan akhlak. Ath-Thabari mengatakan manusia pada masa itu berada pada tahap paling rendah kerana tidak lagi mempunyai sebarang sekatan sehinggakan boleh memasuki rumah seseorang lalu merampas rumah, isteri dan seisi harta rumah tersebut. ${ }^{25}$ Kepincangan yang berlaku telah merangkumi satu kerajaan iaitu dari pemimpin dan para pembesarnya hingga kepada rakyat jelata yang terencah dengan ajaran tersebut.

Oleh itu, kemerosotan akhlak dan ketempangan tamadun yang sedang berlaku ini kerana tiadanya satu jalan yang membendung keterbatasan dan kegelapan yang telah membawa manusia jauh daripada fitrah kemanusiaan ${ }^{26}$ Agama Islam datangnya dengan penuh sinar yang mengusir kegelapan yang sedang menyelimuti umat pada ketika itu. Kedatangan Islam dikenal dengan ajaran al-Quran yang dibawa oleh Rasulullah SAW yang merupakan utusan dari Allah kepada manusia. Perjalanan sirah Rasulullah SAW dalam menyebarkan agama ketauhidan kepada Allah yang Esa telah membuka satu peradaban Islam yang cemerlang sekaligus merombak seluruh aspek dari sudut pemikiran, politik, syariat, masyarakat dan ekonomi yang telah ada sebelum kedatangan Islam. $^{27}$

Dari titik inilah, perjalanan sirah Rasulullah SAW telah memainkan peranan. Mempelajari sirah Nabi ini bukanlah semata-mata untuk mengetahui peristiwa menarik dan aneh yang berlaku di zaman Nabi SAW. ${ }^{28}$ Pengkajian sirah ini juga bukan sekadar ingin mengetahui peristiwa-peristiwa yang telah melakar sejarah sebagaimana kajian-kajian sejarah yang lain sebagai contoh sejarah hidup

\footnotetext{
25 Ath-Thabari, Muhammad bin Jarir Abu Jaafar, Tarikh Al-Umam Wa Al-Muluk (Beirut: Dar al-Kutub al-Ilmiah, 1987).

${ }^{26}$ Ath-Thabari, Muhammad bin Jarir Abu Jaafar.

${ }^{27}$ Ath-Thabari, Muhammad bin Jarir Abu Jaafar.

${ }^{28}$ Nik Abdul Aziz Nik Mat, Sirab Nabawiyab: Insan Teladan Sepanjang Zaman (Kuala Lumpur: Nufair Street Sdn. Bhd, 2006).
} 
seorang khalifah atau sejarah tamadun yang silam. ${ }^{29}$ Sirah juga bukanlah sekadar satu kisah yang dibaca pada hari keputeraan baginda SAW sahaja. ${ }^{30}$

Akidah umat yang dahulunya sebelum kedatangan Islam berada dalam kepincangan dan kemerosotan yang melampau telah kembali bersinar dengan ketauhidan dan akidah yang benar kepada Allah SWT. Abu Zaid Syalabi dalam kitab Tarikh al-Hadharah al-Islamiyah wa al-Fikr al-Islamiy mengatakan setelah kedatangan Islam dan kaum Muslimin berjaya menakluki negara Parsi, penduduk Parsi sekaligus bercampur dan bergaul dengan kaum Muslimin. ${ }^{31}$ Pergaulan yang berlaku secara baik itu telah memberikan banyak pengetahuan kepada rakyat Parsi tentang kebaikan Islam dan perlahan-lahan cuba bertoleransi secara baik dengan Islam. Ternyata inilah kehebatan Islam yang merupakan agama persaudaraan dan persamaan, mendekati penganutnya dengan penuh kelembutan sehingga saling berkasih sayang dengan penuh cinta antara satu sama lain. ${ }^{32}$

Bagi Abu Zaid Syalabi, ajaran sedemikian yang dibawa oleh Islam inilah yang membuka hati rakyat Parsi untuk memeluk Islam secara suka rela. ${ }^{33}$ Mereka bahkan berminat dan sekaligus mempelajari bahasa Arab. Bahasa Arab akhirnya telah menjadi satu bahasa yang begitu mereka cintai dan dipegang erat dalam membantu mereka memahami Islam dan mentadaburinya dengan baik. ${ }^{34}$

Melihat kepada semua kehancuran dan kemerosotan tadi, jelas menunjukkan kepada kita bahawa sekiranya masayarakat seluruh dunia pada hari ini meneliti dan mengkaji sirah yang terdahulu, maka corak dan acuan penghidupan masyarakat akan bergerak ke arah pembentukan manusia yang terpuji yang mempunyai sifat-sifat amanah, pemurah, suka menolong dan bencikan kezaliman serta kemewahan yang boleh membawa kepada pembaziran ${ }^{35}$

Oleh itu, dari sinilah kita dapat meneroka besar dan manfaatnya peranan sirah dalam membentuk ketamadunan dan pegangan akidah umat. Sejarah keruntuhan tamadun yang telah berlaku menjelaskan kepada kita

\footnotetext{
${ }^{29}$ Muhammad Said Ramadan al-Buti, Hadha Waladi. Damsyik: Dar Al-Fikr, 1998.

${ }^{30}$ Muhammad al-Ghazali, Terj.Figh Sirah (Kuala Lumpur: Pustaka Salam, 2010).

31 Abu Zaid Syalabi, Tarikh Al-Hadharah Al-Islamiyyah Wa Al-Fiker Al-Islami (Kairo: Maktabah Wahbah, 2004).

32 Abu Zaid Syalabi.

${ }^{33}$ Abu Zaid Syalabi.

${ }^{34}$ Abu Zaid Syalabi.

${ }^{35}$ Muhammad Said Ramadan al-Buti, Hadha Waladi. Damsyik: Dar Al-Fikr.
} 
pokok utama sesebuah ketamadunan adalah ketauhidan dalam beragama. Sekiranya tiada lagi roh-roh keagamaan dalam sesebuah bangsa, maka seluruh bangsa itu akan terencah dalam kemerosotan akhlak yang paling rendah. ${ }^{36}$ Bagi Raghib Sirjani, apa yang telah berlaku dalam kemerosotan tamadun yang terdahulu adalah penting sebagai satu pemberian yang patut diperhatikan kerana ia telah membuka akal manusia untuk menerima pancaran akidah yang baru dari peradaban Islam. ${ }^{37}$

2. Sirah Menggambarkan Kebudayaan

Sirah Rasulullah SAW turut menyerlah dalam menyebarkan budaya yang baik dan sejajar dengan kehendak Islam. Perkara ini dapat dilihat apabila Syeikh Ramadan al-Buti menyentuh tentang budaya semulajadi ke arah penghidupan seorang manusia yang mempunyai kemahuan kuat ke arah pembentukan manusia terpuji yang mempunyai sifat-sifat amanah, pemurah, suka menolong dan bencikan kezaliman. ${ }^{38}$ Budaya inilah yang dibawa oleh oleh Rasulullah SAW dalam sisi dakwah baginda sejak diutuskan kepada masyarakat Semenanjung tanah Arab.

Empat peradaban besar yang sezaman dengan bangsa Arab pada ketika itu ialah negara Rom, Parsi, Greek Tua dan India berada dalam keadaan huru-hara dengan kezaliman dan kebinasaan yang melampau. ${ }^{39}$ Walau bagaimanapun, kepincangan yang sedang berlaku dalam empat negara besar itu tidak mempengaruhi budaya kejahilan yang ada pada bangsa Arab. Jawwad Ali dalam kitabnya al-Mufashshal fi Tarikh al-Arab Qabla al-Islam menyebut bangsa Arab menjelang munculnya Islam, mereka dikenali dengan sebutan Tarikh al-Jahiliyah yang dimaksudkan kepada kekolotan dan perpecahan. ${ }^{40}$ Kelompok bangsa Arab pada ketika itu berada dalam keadaan berpecah belah dengan kelompok sekitarnya dalam hal peradaban. Mereka berada dalam budaya kebodohan dan kelalaian mereka yang tersendiri sehinggakan sebahagian besar dari mereka hidup dalam kabilah-kabilah yang sering berpindah randah tanpa arah tuju yang jelas. ${ }^{41}$

\footnotetext{
${ }^{36}$ Abu Zaid Syalabi, Tarikh Al-Hadharah Al-Islamiyyah Wa Al-Fiker Al-Islami.. 2004. Tarikh alHadharah al-Islamiyyah wa al-Fiker al-Islami.

${ }^{37}$ Rahgib as-Sirjani, Sumbangan Peradaban Islam pada Dunia.

${ }^{38}$ Muhammad Said Ramadan al-Buti, Hadha Waladi. Damsyik: Dar Al-Fikr.

${ }^{39}$ Ibid.

${ }^{40}$ Jawwad Ali, Al-Mufashshal Fi Tarikh Al-Arab Qabla Al-Islam (Dar as-Saqi, 2001).

${ }^{41}$ Ibid.
} 
Masyarakat Arab pada masa jahiliyah, mereka mempunyai akhlak dan budaya peradaban yang tersendiri. Abu Hasan an-Nadawi menyatakan bahawa masyarakat Arab pada ketika itu menonjol dalam aspek kesasteraan seperti bayan. Mereka juga kuat dengan budaya yang suka dengan kebebasan dan harga diri, bermegah-megahan membanggakan keberanian dan rela berjuang terhadap apa yang diyakini. ${ }^{42}$ Apa yang lebih menarik, bangsa Arab terkenal sebagai bangsa yang tidak berputar belit dalam percakapan. Mereka begitu jelas dalam ucapan dan sangat setia menjaga kehormatan serta amanah dalam memegang janji yang telah dipersetujui. ${ }^{4 .}$

Jawwad Ali mengatakan masyarakat Arab langsung tidak mengetahui kekusustan yang sedang berlaku kepada dunia luar pada ketika itu. Mereka tidak pula mengambil langkah untuk berinteraksi dengan peradaban luar lain. ${ }^{44}$ Mereka hanya hidup dengan budaya penyembahan berhala yang tersebar hampir kepada seluruh puak kabilah sehinggakan hampir setiap rumah didapati adanya berhala. ${ }^{45}$ Walau bagaimanapun, menurut Abu Hasan an-Nadawi menjelang sisi-sisi kemunculan Islam, bangsa Arab mendapat bencana kerana tiadanya cahaya utusan dan petunjuk yang sampai kepada mereka. Berlaku kemunduran yang teruk terhadap agama. Mereka menjadi penyembah berhala yang luar biasa dan taklid teguh dengan agama nenek-moyang mereka. ${ }^{46}$

Walau bagaimanapun bagi Syeikh Ramadan al-Buti, silap apabila sesetengah golongan mengatakan bahawa pengikut-pengikut agama yang sesat adalah sukar untuk diubati jiwa meraka apatah lagi untuk memberi tunjuk ajar kepada mereka. ${ }^{47}$ Ini kerana mereka ini dikatakan taksub (fanatik), berbangga dengan keburukan, kehancuran dan kemusnahan yang telah mereka lakukan yang pada sangkaan mereka semuanya adalah baik. Setelah dikenal pasti, sebenarnya mengubati dan memberi tunjuk ajar kepada mereka yang sedang mencari-cari kebenaran adalah lebih mudah kerana mereka ini sama sekali tidak menafikan kejahilan mereka sendiri dan tidak pula berbangga atau bermegah-megah dengan hasil tamadun kerana mereka langsung tidak mempunyai tamadun untuk dimegahkan. ${ }^{48}$

\footnotetext{
${ }^{42} \mathrm{Abu}$ al-Hasan an-Nadawi, Madza Khasira Al-Alam Bi Inbithath Al-Muslimin.

43 Abu al-Hasan an-Nadawi.

${ }^{44}$ Jawwad Ali, Al-Mufashshal Fi Tarikh Al-Arab Qabla Al-Islam.

45 Ibid.

${ }^{46}$ Ibid.

47 Ibid.

${ }^{48}$ Muhammad Said Ramadan al-Buti, Hadha Waladi. Damsyik: Dar Al-Fikr.
} 
Hasilnya, sirah Rasulullah SAW telah menunjukkan kepada kita tentang pemilihan semenanjung Arab sebagai tempat titik munculnya Baginda Rasulullah SAW dalam permulaan awal dakwah. Hal ini kerana, menurut Syeikh Ramadan al-Buti dalam kitab Fiqh as-Sirah menyebut bahawa budaya dan tatasusila bangsa Arab ini tidak ubah seakan suatu "bahan mentah" yang belum pernah dileburkan oleh mana-mana dapur dan dicorakkan oleh mana-mana acuan. ${ }^{49}$ Bangsa Arab langsung tidak pernah merasai kemewahan dan kemajuan seperti Parsi yang boleh membawa mereka ke arah kerosakan dan keruntuhan akhlak yang melampau. Mereka juga tidak pula mengagung-agungkan kekuatan tentera yang membolehkan mereka menjajah negara-negara sekitarnya. Dalam hal keagamaan pula, mereka tidak menganut falsafah dan ideolagi yang berbagai seperti apa yang dilakukan oleh Greek Tua yang akhirnya menyebabkan mereka menjadi bangsa yang tenggelam ke dasar lautan khurafat yang tidak memberi sebarang faedah..$^{50}$

Abu Zaid Syalabi menyarankan supaya memperhatikan keadaan bangsa Arab sebelum Islam dengan keadaan mereka selepas masuknya Islam ke dalam peradaban mereka. ${ }^{51}$ Rasulullah SAW telah menunjukkan kepada bangsa Arab bagaimana kemudahan Islam yang dibawa oleh baginda sebagai satu perkara untuk memperbaharui keadaan bangsa Arab pada ketika itu. Budaya masyarakat Semenanjung Arab pada ketika itu berada dalam keadaan yang jauh dan terpencil dari gejala dan budaya masyarakat yang huru hara tadi. Apa yang mereka perlukan adalah pengetahuan yang dapat menyinari jalan ke arah pembentukan manusia yang terpuji yang dilatari dengan akhlak yang baik, amanah, bencikan kezaliman dan saling membantu ke arah perkara kebaikan. ${ }^{52}$

Justeru itu, bagi Abu Zaid Syalabi Islamlah satu-satunya agama yang mampu meluruskan akhlak, melembutkan jiwa, menyatukan kalimat, memperbaiki masyarakat, meninggikan urusan dan memuliakan sesama mereka. ${ }^{53}$ Dengan agama Islam inilah mereka telah menjadi umat yang mempunyai hala tuju dan matlamat hidup sedangkan sebelumnya mereka

\footnotetext{
49 Muhammad Said Ramadan al-Buti, Fiqh As-Sirah an-Nabawiyyah (Damsyik: Dar al-Farabi, 2006).

${ }^{50}$ Ibid.

51 Ibid.

52 Ibid.

${ }^{53}$ Ibid.
} 
tidak pernah mengambil tahu semua itu. Mereka telah mendapat petunjuk dari jalan kegelapan yang ada pada mereka sebelum ini seakan satu kebangkitan dan permulaan yang baru dari lena yang panjang dalam kelesuan. $^{54}$

Raghib ar-Sirjani menyebut, kajian sejarah Islam itu pada permulaannya adalah tentang sirah Rasulullah SAW dalam menyebarkan dakwah. ${ }^{55}$ Hakikatnya, jika masyarakat pada hari ini mengambil perhatian lebih akan perjalanan sirah Rasulullah SAW dalam membawa suatu budaya yang menurut kehendak Islam, nescaya aspek budaya sosial yang baik untuk umat Islam hari ini dapat dilaksanakan. ${ }^{56}$ Menurut Russel sekiranya sejarah Islam ini diberi lebih perhatian, budaya umat islam dapat berkembang dalam dasar komuniti yang diperlukan oleh umat Islam untuk pembangunan masyarakat Islam. ${ }^{57}$

\section{Sistem Kemasyarakatan dalam Sirah}

Syeikh Ramadan al-buti ada menekankan tentang kemasyarakatan Islam yang baik berdasarkan sirah Rasulullah SAW. Menurut Raghib asSirjani, masyarakat Islam terbina hasil dari kumpulan keluarga besar yang saling mengikat jalinan cinta dan saling menjamin, tolong-menolong dan berkerjasama antara satu sama lain. ${ }^{58}$ Jalinan ini membentuk kumpulan masyarakat rabbani, berperikemanusiaan dan berperilaku seimbang. Setiap individu hidup dalam kemuliaan akhlak yang menjadikan meraka berinteraksi secara adil dan musyawarah dalam menyelesaikan sesuatu permasalahan. ${ }^{59}$

Bagi Syeikh Ramadan al-Buti, pentingnya masjid dalam membina tapak sesebuah masyarakat Islam sebagai satu arah kepada pembentukan negara Islam yang kukuh dan kemas. ${ }^{60}$ Rasulllah SAW sendiri, sebaik sahaja baginda tiba di Madinah dan menetap di sana, baginda Rasulullah SAW terus membina sebuah masjid yang terdiri daripada batu-batu, batang-

\footnotetext{
${ }^{54}$ Ibid.

${ }^{55}$ Rahgib as-Sirjani, Sumbangan Peradaban Islam pada Dunia.

${ }^{56}$ Ibid.

${ }^{57}$ Ibid.

${ }^{58}$ Ibid.

${ }^{59}$ Ibid.

${ }^{60}$ Muhammad Said Ramadan al-Buti, Fiqh As-Sirah an-Nabawiyyah.
} 
batang tamar dan pelepah-pelepah tamar. Ini menjelaskan tentang masjid sebagai satu markas peradaban Islam. ${ }^{61}$

Tambahan pula, Abdullah al-Masyukhi dalam kitab Manqif al-Islam wa al-Kanisah Min al-Ilm menyatakan bahawa Rasulullah SAW menjadikan Masjid Madinah sebagai tempat untuk pendidikan, tempat berkumpul yang utama bersama para sahabat dan tempat untuk menyampaikan wahyu alQuran. ${ }^{62}$ Masjid digunakan oleh Rasulullah untuk mengajarkan hukumhukum agama sama ada dengan ucapan atau perbuatan. ${ }^{63}$ Peranan masjid yang berguna sebagai satu prasarana untuk mengajarkan risalah al-Quran berlanjutan sampai kepada zaman Khulafa ar-Rasyidin dan begitu pula seterusnya peranan masjid sampai kepada Bani Umayyah, Abbasiyah dan selepasnya. ${ }^{64}$

Hal ini kerana, masjid sebenarnya merupakan tempat yang menjadi sumber suntikan kekuatan dan semangat kepada masyrakat Islam. Ini kerana melalui masjidlah segala sistem Islam, akidah dan kepercayaaan serta peradaban Islam yang sebenarnya dapat dilaksanakan secara menyeluruh dan konsisten. Di antara sistem peradaban Islam ialah dengan meluaskan roh persaudaraan dan ikatan mahabbah sesama umat Islam. Disinilah dapat kita rungkaikan sumbangan Sirah dalam sistem kemasyarakatan Islam sehingga ke hari ini. ${ }^{65}$

Masjid juga menurut al-Khatib al-Baghdadi menjadi pusat para penuntut ilmu untuk sama-sama berkumpul dan belajar dalam halaqah yang besar. Sesiapa sahaja yang inginkan ilmu dan cinta akan ilmu akan hadir dalam halaqah tersebut. Ibnu katsir menyebut bahawa halaqahhalaqah ilmu di masjid pada ketika itu dihadiri oleh setiap penjuru masyarakat Islam yang suka mencari ilmu, walaupun mereka itu adalah seorang mujtahid atau ulama yang mempunyai kedudukan tinggi di suatu kaum. ${ }^{66}$

Jika diperhatikan, pertemuan yang berlaku dimasjid semasa halaqah ilmu sebeginilah dapat membentuk satu tautan persaudaraan yang fleksibel

\footnotetext{
${ }^{61}$ Ibid.

${ }^{62}$ Abdullah al-Masyukhi, Manqif Al-Islam Wa Al-Kanisah Min Al-Ilm Jordan: Maktabah alManar, 1982).

${ }^{63}$ Ibid.

${ }^{64}$ Ibid.

${ }^{6}$ Ibid.

${ }^{66}$ Ibnu katsir. Abu al-Fida' Ismail, Al-Bidayah Wa An-Nihayah (Tahqiq: Dar al-Kutub al-Ilmiah, 1988).
} 
dengan mengenepikan segala pangkat, kedudukan atau keturunan bahkan juga kekayaan. Dari sinilah umat Islam dapat mengikat tali persaudaraan dan ikatan mahabbah sesama umat Islam. Semangat persaudaraan dan agak sukar untuk dieratkan jika bukan melalui masjid. Oleh itu, masjid merupakan tempat paling ideal bagi umat Islam berkumpul dan bertemu dalam kelompok yang berbeza dan jauh lebih besar. ${ }^{67}$

Selain itu, melalui tautan persaudaraan tadilah akan membawa kepada semangat kemasyarakatan yang adil dan saksama di kalangan umat Islam di segenap lapisan hidup dan aspek. Menurut Abdullah al-Masyukhi, masjidlah yang telah mengatur pertautan semangat persaudaraan yang utuh sesama umat Islam itu sendiri. ${ }^{68}$ Berbagai bidang ilmu yang telah diajar di masjid baik secara aqliyah mahupun naqliyah telah berjaya membentuk jati diri dan akidah umat islam dari hari ke sehari.

Oleh itu, perkara ini jelas menunjukkan bagaimana sirah telah mengajar kita agar mula bermasyarakat dengan mempertaut tali persaudaraan terlebih dahulu. Kita seharusnya berkumpul dan bersilaturrahim antara satu sama lain. Dari situ lah baru kita dapat membentuk masyarakat yang berpegang dengan hukum Allah dan syariatnya. Keberadaan berdiri dalam satu saf yang sama menunjukkan kepada kita juga bahawa disisi Allah, semua manusia itu nilaianya sama melainkan ketakwaan dalam hati dan sanubari yang membezakan darjat kita kelak. $^{69}$

\section{Sirah Mengajarkan Ekonomi Islam}

Ekonomi sebelum zaman kedatangan Islam dan pengutusan baginda Rasulullah SAW di Mekah menunjukkan bahawa masyarakat Quraisy pada ketika itu bertani, menternak dan berdagang sebagai mata pendapatan mereka. Mereka bagaimanapun menjadikan riba sebagai tradisi muamalat sesama mereka. Mereka telah terpengaruh dengan sistem riba yang telah diamalkan oleh barat. ${ }^{70}$

Syeikh Ramadan al-Buti dalam kitab Figh as-Sirah an-Nabawiyyah menjelaskan bagaimana ekonomi yang dilaksanakan oleh baginda Rasulullah SAW. Menurut al-Mubarakfuri, baginda mula mengikuti bapa

\footnotetext{
${ }^{67}$ Muhammad Said Ramadan al-Buti.

${ }^{68}$ Abdullah al-Masyukhi. 1982. Manqif al-Islam wa al-Kanisah Min al-Ilm

${ }^{69}$ Muhammad Said Ramadan al-Buti, Fiqh As-Sirah an-Nabawiyyah.

${ }^{70}$ Ibid.
} 
saudaranya Abu Talib ke Syam untuk berdagang mencari rezeki yang halal sejak berusia 12 tahun lagi. Semakin umur baginda menginjak dewasa, baginda semakin cergas mencari rezeki dan memulakan pernigaan sendiri.

Perniagaan Rasulullah SAW semakin berjaya dan seringkali mendatangkan keuntungan setiap kali keluar berdagang. Perkara ini menyebabkan baginda arif dalam hal-hal perniagaan kerana sudah banyak menceduk segala ilmu hasil dari pengalaman baginda sendiri menguruskannya. Bagi al-Mubarakfuri, kejayaan Rasulullah sebagai ahli perniagaan adalah bukan kerana status kenabian dan kerasulan sematamata, akan tetapi ia adalah hasil daru usaha gigih serta ilmu perniagaan yang dikuasai oleh baginda.

Perkara ini jelas menunjukkan kepada kita bahawa sebaik-baik harta adalah hasil dari perusahaan sendiri demi untuk kebaikan masyarakat dan manusia sejagat. Apa yang pasti, seburuk-buruk kesenangan adalah kemewahan yang diperolehi tanpa usaha dan kesusahan yang langsung tidak memberi sebarang sumbangan kepada masyarakat. ${ }^{71}$

Ciri-ciri inilah yang wajar dicontohi oleh seluruh pendakwah bahkan sirah Rasulullah telah menunjukkan kepada kita bagaimana baginda Rasulullah SAW berusaha sendiri dan tidak bergantung kepada pemberian dan sedekah selepas berdakwah. Ini menjelaskan bahawa sebaik-baik pendakwah ialah yang berdikari dan bergantung kepada sumber-sumber kewangan dan perusahaan sendiri tanpa meminta dari manusia lain ${ }^{72}$

Menurut Afzalur Rahman, sirah membuktikan sisi-sisi kemunculan pengurusan ekonomi secara Islam apabila baginda dipelawa oleh Saidatina Khadijah untuk menjalankan perniagaan dengan hartanya sebagai modal utama. ${ }^{73} \mathrm{Hal}$ ini adalah kerana peribadi yang mulia dan kesungguhan yang tinggi dalam pekerjaan yang telah ditunjukkan oleh Rasulullah SAW. Sikap "al-amin" yang disandarkan kepada Rasulullah SAW sekaligus menutup isu yang sedang diperkatakan pada ketika iaitu ketiadaan orang yang benarbenar boleh dipercayai untuk diberikan modal berniaga. ${ }^{74}$ Sifat amanah baginda ini seharusnya menjadi satu inspirasi yang besar kepada seluruh

\footnotetext{
${ }^{71}$ Muhammad Said Ramadan al-Buti. 1998. Hadha Waladi.

${ }^{72}$ Muhammad Said Ramadan al-Buti, Fiqh As-Sirah an-Nabawiyyah.

${ }^{73}$ Afzalur Rahman, Ensiklopedia Sirah Nabawiyah (Kuala Lumpur: Dewan Bahasa dan Pustaka, 2002).

${ }^{74}$ Ibid.
} 
mukmin supaya sentiasa bersikap telus dan jujur dalam setiap perkara dengan tidak sewenang menggunakan harta yang bukan milik kita. ${ }^{75}$

Sirah juga telah menunjukkan setelah berlaku penghijrahan ke Madinah, banyak perubahan yang telah dilakukan oleh baginda Rasulullah SAW. Menurut al-Qardawi, ketika di Madinah, baginda Rasulullah SAW sendiri yang membangunkan pasar berorientasikan syariat Islam. ${ }^{76}$ Pasar itu bukanlah seperti pasar yang dikuasai oleh orang-orang Yahudi seperti Pasar Qainuqa' dulu. Rasulullah SAW mengawasi pasar tersebut. Baginda telah menggariskan segala perngurusan serta memberi bimbingan dan pengarahan kepada masyarakat setempat. ${ }^{77}$

Ketika di Madinah juga, menurut Afzalur Rahman, Rasulullah s.a.w. telah mengemaskinikan pungutan zakat, cukai ghanimah, fai' dan kharaj. ${ }^{78}$ Menurut Syeikh Ramadan al-Buti, golongan Yahudi adalah kapitalis yang menguasai ekonomi Madinah ketika itu. Mereka mengaut keuntungan tanpa perhitungan moral. ${ }^{79}$ Justeru itu Rasulullah memberi galakan kepada orang Islam untuk menceburkan diri dalam bidang perniagaan bagi memecah monopoli yang selama ini dilakukan oleh orang Yahudi. ${ }^{80}$ Dengan cara ini masyarakat Islam dapat memecah jaringan kewangan golongan Yahudi yang memerangkap orang-orang miskin dengan memberi pinjaman atas kadar faedah yang tinggi. Rasulullah s.a.w. juga memberi perhatian kepada bidang penternakan dan pertanian. ${ }^{81}$

Oleh itu, disini jelas menunjukkan bahawa melalui sirah Rasulullah SAW, umat Islam pada harini ini dapat memacu sistem ekonomi Islam yang berlandaskan al-Quran dan al-Sunnah seiring dengan sirah yang telah dilaksanakan oleh Rasulullah SAW mengikut peredaran zaman. Manusia yang pada zaman jahiliyah tidak amanah dengan melakukan penyalahgunaan wang, syubhat serta mengamalkan riba dalam urusan perniagaan dan perdagangan telah berjaya diperbetulkan oleh baginda Rasulullah SAW ke arah pengurusan ekonomi secara Islam. Bagi Syeikh Ramadan al-Buti, sebagai mukmin yang mempunyai kasih dan cinta akan

\footnotetext{
75 Ibid.

76 Yusuf al-Qardawi, Al-Hulul Al-Mustwaradah Wa Kayfa Janat 'ala Ummaatina (Penyelesaian Import: Bagaimana Ia Menghentam Umat Kita)., 1983rd ed. (Kaherah: Maktabah Wahbah, n.d.).

77 Ibid.

78 Afzalur Rahman, Ensiklopedia Sirah Nabawiyah.

${ }^{79}$ Muhammad Said Ramadan al-Buti, Hadha Waladi. Damsyik: Dar Al-Fikr.

${ }^{80}$ Muhammad Said Ramadan al-Buti, Figh As-Sirah an-Nabawiyyah.

${ }^{81}$ Ibid.
} 
Rasulullah SAW, kita sewajarnya berusaha mengikuti adunan penghidupan yang telah diamalkan oleh baginda Rasulullah SAW. ${ }^{82}$

\section{Simpulan}

Sirah Rasulullah SAW menjadi satu asas pengetahuan yang penting terutamanya kepada umat Islam pada hari ini. Hal ini kerana, dalam konteks kemodenan sekarang pendedahan sirah merupakan salah satu cabang penting kepada umat Islam supaya menelusuri aspek keislaman lengkap yang telah teradun dalam diri Rasulullah SAW. Banyak teladan dan contoh ikutan yang telah ditunjukkan oleh junjungan besar Nabi Muhammad SAW sebagai pedoman kepada umat manusia. Sesungguhnya kehidupan umat Islam tidak dapat lari daripada menjadikan Rasulullah sebagai model ikutan sepanjang zaman. Kitab Fiqh as-Sirah an-Nabawiyyah yang telah dikarang oleh Syeikh Ramadan al-Buti amat wajar dibaca dan difahami oleh seluruh umat Islam. Hal ini kerana, dalam kitab ini Syeikh Ramadan al-Buti telah membahagikannya kepada beberapa bahagian yang tertib. Beliau juga telah mendatangkan pengajaran yang boleh diambil oleh umat Islam di setiap akhir bab. Justeru, melalui pemahaman umat Islam terhadap sirah Rasulullah SAW yang telah dikarang oleh ulama, semoga ia dapat mendorong masyarakat mencapai kemajuan dalam hidup sebagaimana baginda yang telah menampilkan transformasi yang besar kepada aspek sosial masyarakat, aspek pemerintahan dan aspek keteladanan yang harus dicontohi umat Islam.

\section{Daftar Pustaka}

Ali, Jawwad. Al-Mufashshal Fi Tarikh Al-Arab Qabla Al-Islam. Dar as-Saqi, 2001. al-Bakri, Zulkifli. Syarah Al-Hikam. Jil.1. Negeri Sembilan: Jabatan Mufti, 2006. al-Buti, Muhammad Said Ramadan. Fiqh As-Sirah an-Nabawiyyah. Damsyik: Dar al-Farabi, 2006.

- Hadha Waladi. Damsyik: Dar Al-Fikr, 1998.

Christmann, Andreas. Islamic Scholar and Religious Leader: A Portrait of Shaykh Mubammad Sa'id Ramadhan Al-Buti. London: I.B. Tauris, 1998.

Damronih. Pengenalan: Pengantin Syurga. Jakarta Timur: Dar al-Fikr, 2009.

Ghazali, Mohd Rumaizuddin. Pandangan Akidah Muhammad Sa'id Ramadhan AlButi Dalam Buku Kubra Al-Yaqiniyyat Al-Kawniyyat, 2011.

al-Ghazali, Muhammad. Terj.Fiqh Sirah. Kuala Lumpur: Pustaka Salam, 2010.

${ }^{82}$ Muhammad Said Ramadan al-Buti, Hadha Waladi. Damsyik: Dar Al-Fikr. 
Ibnu katsir. Abu al-Fida' Ismail. Al-Bidayah Wa An-Nibayah. Tahqiq: Dar alKutub al-Ilmiah, 1988.

al-Masyukhi, Abdullah. Manqif Al-Islam Wa Al-Kanisah Min Al-Ilm. Jordan: Maktabah al-Manar, 1982.

an-Nadawi, Abu al-Hasan. Madza Khasira Al-Alam Bi Inbithath Al-Muslimin. Kairo: Maktabah as-Sunnah, 1990.

Nik Mat, Nik Abdul Aziz. Sirah Nabawiyab: Insan Teladan Sepanjang Zaman. Kuala Lumpur: Nufair Street Sdn. Bhd, 2006.

Rahman, Afzalur. Ensiklopedia Sirah Nabawiyah. Kuala Lumpur: Dewan Bahasa dan Pustaka, 2002.

Sanawi, Mohd Darus \& Mohd Yusuf Haji Ismail. Terj. Fiqh as-Sirah. Selangor: Dewan Pustaka Fajar, 2008.

Syalabi, Abu Zaid. Tarikh Al-Hadharah Al-Islamiyyah Wa Al-Fiker Al-Islami. Kairo: Maktabah Wahbah, 2004.

Ath-Thabari, Muhammad bin Jarir Abu Jaafar. Tarikh Al-Umam Wa Al-Muluk. Beirut: Dar al-Kutub al-Ilmiah, 1987.

as-Sirjani, Rahgib. Sumbangan Peradaban Islam pada Dunia. Jakarta: Pustaka alKautsar, 2006.

The Royal Islamic Strategic Studies Centre. The 500 Most Influential Muslims In The World 2010. Urdun: al-Mamlukak al-Urduniyyah al-Hashimiyyah, 2010.

al-Qardawi, Yusuf. Al-Hulul Al-Mustwaradah Wa Kayfa Janat 'ala Ummaatina (Penyelesaian Import: Bagaimana Ia Menghentam Umat Kita). 1983rd ed. Kaherah: Maktabah Wahbah, n.d.

Wahab, Muhammad Rashidi \& Syed Hadzrullathfi Syed Omar. Kerangka Asas Pemikiran Tokoh Ulama Akidah Kontemporari: Mubammad Sa’id Ramadhan Al-Buti. Bangi: UKM, 2011. 